AKRUAL 7 (1) (2015): 85-90 $e$-ISSN: 2502-6380

\title{
AKRUAL
}

Jurnal Akuntansi

http://journal.unesa.ac.id/php.index/aj

\section{Reformasi Gereja; Pemeliharaan Legitimasi}

\author{
Rohmawati Kusumaningtias \\ Fakultas Ekonomi, Universitas Negeri Surabaya \\ rohmawatikusnitia@yahoo.co.id
}

\begin{abstract}
Abstrak
Akuntansi memainkan peran yang krusial di setiap kepentingan. Sebagai alat untuk pengambilan keputusan dalam perolehan laba di masa industri merupakan hal yang telah diketahui secara umum. Quattrone (2004) menyajikan akuntansi dari sisi yang berbeda, yaitu sebagai alat pengendalian internal organisasi dan penelusuran moral anggota jamaah. Artikel ini mencoba melihat akuntansi yang disampaikan Quattrone dalam balutan teori Foucault tentang geneologi kekuasaan.
\end{abstract}

Keywords: gereja, accounting for sins, Foucault

\section{PENDAHULUAN}

Pada masa revolusi industri, akuntansi merupakan alat krusial yang digunakan dalam pengambilan keputusan untuk pencarian laba. Berbeda pandangan dengan hal tersebut, Quattrone (2004) menyajikan akuntansi sebagai alat dalam lembaga keagamaan Gereja Roma,yang disebut sebagai jamaah Jesuit Order (atau Society of Jesus). Saint Ignatius merupakan pencetus metode ini, yang membagi fungsi akuntansi menjadi tiga, yaitu accounting for sins, accounting for college, dan accounting for soul.

Sejarah mengungkapkan pada awal abad 11 hingga 14 terjadi pemberontakan yang disebut sebagai reformasi Protestan yang berlanjut pada tindakan reformasi Katolik. Dengan kata lain, reformasi Katolik dilakukan untuk mencegah pemberontakan Protestan. Tindakan ini oleh Reinhard (1989) dan Prodi (1987) dikatakan sebagai pergerakan menuju modernitas yang memengaruhi perubahan sejarah dunia pada gereja. Hal ini karena reformasi Katolik merupakan suatu proyek besar dengan jenjang realisasi, merasuk ke dalam masyarakat Eropa, menciptakan pengaruh di setiap struktur organisasi yang bercirikan modernitas.

Reformasi Gereja Katolik Roma disertai dengan pembentukan dewan yang dinamakan Council of Trent ${ }^{1}$ pada abad 16. Saat terjadi pemberontakan, Council of Trent

\footnotetext{
${ }^{1}$ Terdiri dari pendeta senior dengan ketetapan yang mengikat seluruh umat Kristiani.
} 
memisahkan secara jelas antara Katolik dan Lutherian² ${ }^{2}$ Lutherian dianggap sebagai ancaman bagi eksistensi gereja di masyakarat. Maka Council of Trent melakukan reformasi, pembenahan dalam sistem administrasi gereja melalui akuntansi. Tujuannya jelas, yaitu mengembalikan legitimasi kekuasaan gereja sebagai pusat keagamaan dan menertibkan masyarakat. Hal ini mirip dengan kisah Cebolek yang sengaja dipelihara oleh kerajaan pada abad 17 di Indonesia (Kuntowijoyo; 1999). Kemiripan ini akan dibahas pada paragraf lainnya.

Ide dari Lutherian tentu ditolak oleh kalangan gereja. Sedikitpun tidak diberikan ruang untuk interpretasi Al Kitab secara personal (Searle, 1974), maka beberapa hal dilakukan oleh Council of Trent, antara lain memperkuat posisi uskup dengan memperluas otoritas pendeta, melakukan muktamar gereja tahunan, mengadakan seminar di seluruh Eropa dalam rangka pelatihan pendeta. Barisan dirapatkan untuk memperkuat posisi gereja dengan modernisasi sistem kependetaan. Pelan tapi pasti sistem gereja berubah seperti monarchy, seperti yang disampaikan oleh Flannery (1975), Paus dengan supremasi dan kekuatan menyeluruh, tak terintangi. Selain itu, upaya lainnya adalah gereja lebih terbuka untuk seluruh masyarakat, tidak terbatas pada umat Katolik.

Di sisi lain, Jesuit Order merupakan institusi yang mewakili abad pertengahan dengan penekanan pada pedagogikal, misionari, aktivitas ekonomi yang dilakukan secara hirarki, terorganisir dan terkontrol. Hal ini terlihat pada gambar 1.

\footnotetext{
${ }^{2}$ Pendukung Luther, pemberontak sistem gereja. Lutherian berpandangan bahwa keimanan merupakan hak bagi setiap umat, didapatkan dari pembelajaran Al Kitab secara mandiri, bukan dari pengakuan dosa (yang akhirnya diukur sesuai besaran materi). Dengan demikian, peran gereja terutama Paus menjadi berkurang dan terbatas.
} 


\section{Akuntansi: Alat Pengendali Kuasa Gereja}

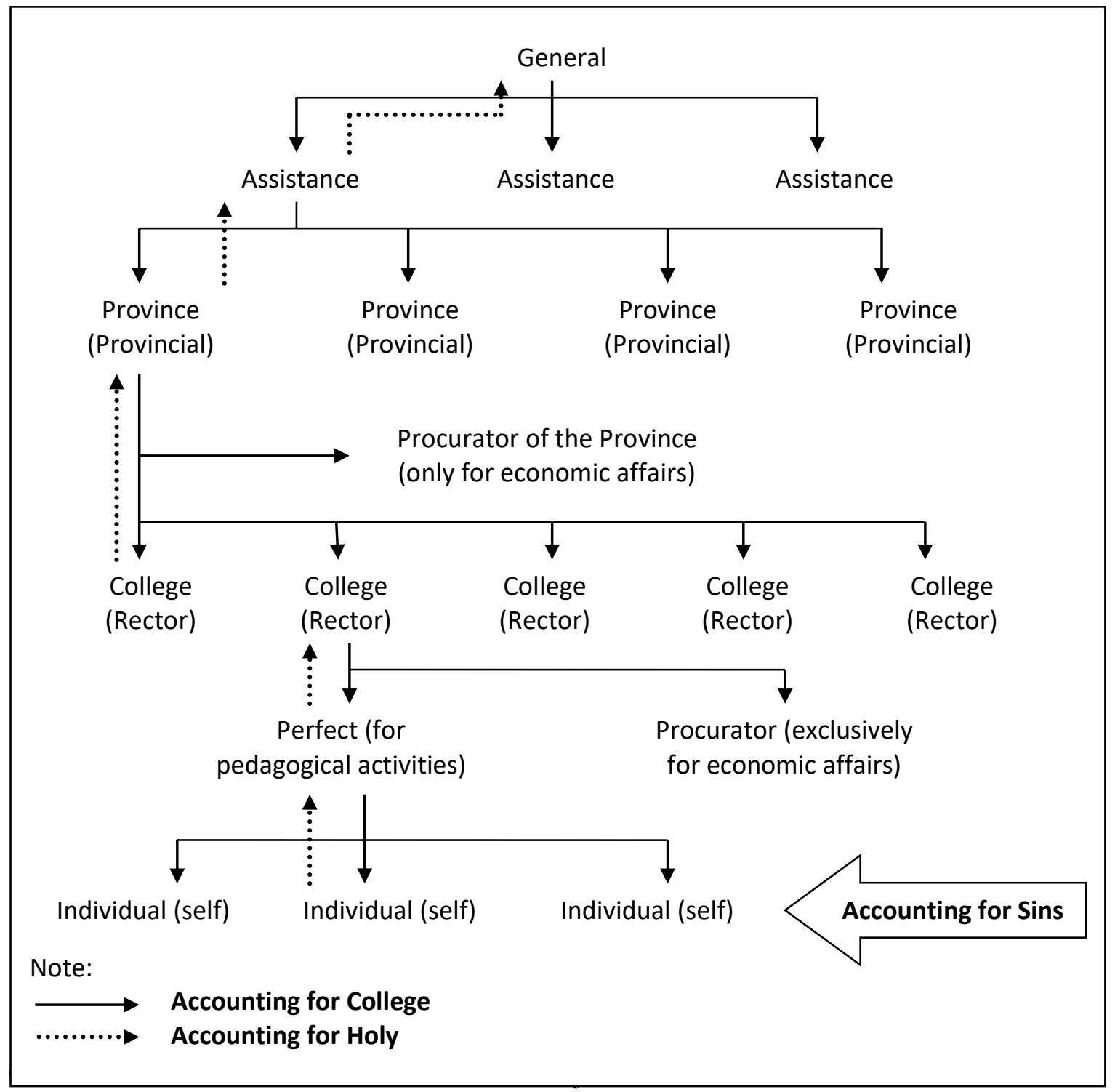

Sumber: Refleksi dari Quattrone (2004)

\section{Accounting for Sins, Ciri Posmodernisme}

Penyebaran melalui pendidikan berlangsung dengan cepat di seluruh daratan Eropa, permasalahan pengendalian telah diantisipasi oleh Ignatius dengan pendekatan kedisiplinan yang ketat melalui Pelatihan Spiritual. Pelatihan ini bersifat personal, membutuhkan sebuah buku (di sini ditemukan maksud dari accounting for sins) untuk menuliskan komitmen moral exercitant ${ }^{3}$ selama hidupnya. Konsep benar-salah ${ }^{4}$ dan etis-

\footnotetext{
${ }^{3}$ Pelaku pelatihan

${ }^{4}$ Konsep benar-salah distandarkan dengan dua hal yang berlawanan, yaitu positif (God) dan negatif (Lucifier).
} 
nonetis digunakan untuk menghitung dosa pribadi, berdealektika individu ${ }^{5}$, kemudian berjanji untuk menjadi umat yang lebih baik, dalam hal ini diperlukan akuntanbilitas diri. Pelatihan Spiritual ini, memerlukan meditasi, kontemplasi diri yang dipraktikkan dengan aksi pada ranah seni, pertunjukkan, dan puisi.

Di sini terletak ciri-ciri posmodernisme. Antara lain, adanya dediferensiasi dengan memasukkan unsur keTuhanan dalam individu. Pencarian Tuhan tidak pernah dikenal dalam modernisme yang bersifat sekuler, memisahkan unsur keduniawian dan agama. Sementara di sini, Ignatius melakukan hal yang sebaliknya. Ciri lainnya adalah aksi kesenian sebagai representasi hasil kontemplasi meditasi. Hasil akhir dari pelatihan ini adalah konsep mengenai Tuhan sesuai dengan persepsi masing-masing individu.

Sementara itu, untuk menghasilkan pendidikan yang mudah diterima, kurikulum disusun sesuai dengan budaya masyarakat. Dalam proses pencarian Tuhan, anak didik dibebaskan dalam berkreasi, tidak dibatasi, bahkan bukan permasalahan, jika harus menolak doktrin gereja. Ini juga yang mencirikan posmodern, tidak ada grand atau meta narasi, dan lebih menghargai mikronarasi.

\section{Accounting for The College, Teknik Pengendalian Organisasi}

Pada masa abad 16, sistem akuntansi sudah menunjukkan akurasi dan kecanggihan. Secara umum, telah mencatat sumber-sumber pemasukan dan alokasi penggunaan biaya. Akuntansi sangat penting memainkan peranannya karena besarnya pendapatan yang masuk digambarkan lebih besar dari pajak daerah saat itu. Sistem Trattato (yang digunakan saat itu) menunjukkan kombinasi analisis dan sintesis yang efektif mencerminkan hierarki organisasi. Teknik akuntansi melayani manajemen di setiap titik hierarki (lihat gambar 1). Telah ada konsep laba rugi dengan alokasi pembiayaan yang cermat, pelaporan dan verifikasi dilakukan di lini horisontal. Sedangkan untuk mencegah berbagai kecurangan, telah dilaksanakan sistem pengendalian manajemen dan sistem auditing.

\section{Accounting for The Soul, Manuskrip Moral Individu}

Teknik akuntansi ini mencakup tiga hal, yaitu (1) catalogous primus, memuat identitas anggota, (2) catalogous secundus, memuat karakter dan perilaku individu, (3) catalogous

\footnotetext{
${ }^{5}$ Dialog yang melibatkan 'aku' dan 'saya' sebagai metode untuk menentukan tindakan benar atau salah, menasihati diri sendiri.
} 
tertius, memuat aktivitas ekonomi, menghasilkan neraca setiap universitas (college). Manuskrip ini dilaporkan kepada kuasa tertinggi yaitu general.

\section{Akuntansi Panoptic Gereja}

Akuntansi model reformasi gereja menjadi alat pengendalian kuasa sekaligus penelusuran individu yang bersifat sederhana namun efektif. Lebih realistis dalam melanggengkan kekuasaan dan mengatur masyarakat daripada metode serat Cebolek yang diterapkan oleh kerajaan Demak pada abad 17 (Kuntowijoyo; 1999). Serat Cebolek yang berisi cerita mengenai individu yang mempraktikkan sufisme dianggap sebagai pemberontak kerajaan. Karena praktik sufisme merupakan ancaman bagi kelangsungan posisi kerajaan di tengah masyarakat. Kondisi ini mirip dengan pemberontakan Lutherian. Namun, kondisi masyarakat Indonesia saat itu yang lebih percaya pada mistisme, menyebabkan kerajaan menerapkan metode kepercayaan, dengan memperlihatkan nasib pemberontak kerjaan yang terasing dan menciptakan mitos kesaktian para raja sebagai titisan dewa atau keturunan nabi. Hal ini tentu saja ditujukan untuk melestarikan kekuasaan dan memelihara loyalitas rakyat kepada rajanya.

Berbeda cara dengan tujuan yang sama,yaitu melestarikan legitimasi, reformasi Gereja Roma menggunakan model yang disebut Foucault (Ritzer, 2012) sebagai panopticon $^{6}$. Teknologi di sini yang dipakai adalah sistem akuntansi dengan ilmunya berfungsi ganda. Pertama, sebagai pengendalian organisasi melalui peraturan (doktrin gereja), kebutuhan subsidi silang entitas ekonomi, pelaporan laba rugi, pengalokasian biaya, sistem pengendalian internal, dan auditing yang tercermin dalam accounting for college (top to the bottom). Kedua, sebagai pengikat perilaku moral jamaah gereja melalui accounting for sins dan accounting for soul (bottom to the top), dalam hal ini diperlukan akuntabilitas individu yang didapat melalui Pelatihan Spiritual. Di sini, terlihat dengan jelas bahwa Councel Of Trent menggunakan akuntansi sebagai teknologi yang berwujud sederhana namun efektif dalam melanggengkan kuasa gereja untuk menghalau krisis Lutherian pada Jesuit Order.

\footnotetext{
${ }^{6}$ berupa menara yang terletak di tengah-tengah sebuah bangunan penjara yang melingkar, sehingga dari tempat itu dapat memeriksa semua sel (top to the bottom), kekuasaanya menjadi semakin kuat saat para tahanan mengontrol diri mereka sendiri (bottom to the top), panopticon berfungsi ganda. Di sinilah keterkaitan antara pengetahuan, teknologi, dan kekuasaan.
} 


\section{Daftar Pustaka}

Kuntowidjojo. 1999. Paradigma Islam: Interpretasi untuk Aksi. Bandung: Penerbit Mizan.

Quattrone, Paolo. 2004. Accounting for God: Accounting and Accountability Practices in The Society of Jesus. Accounting, Organizations, and Society (29), 647-683.

Ritzer, George. 2012. Teori Sosiologi: Dari Sosologi Klasik sampai Perkembangan Terakhir. Edisi Kedelapan. Yogyakarta: Pustaka Pelajar. 